\title{
Decreased coronary artery distensibility measured using 3T MRI is related to systemic inflammation in patients with coronary artery disease
}

\author{
Lia Petrose ${ }^{2}$, micaela iantorno ${ }^{1}$, Sahar Soleimanifard ${ }^{1}$, Sebastian Kelle $^{3}$, Gary Gerstenblith ${ }^{1}$, Robert Weiss ${ }^{1}$, \\ Allison Hays ${ }^{1 *}$
}

From 18th Annual SCMR Scientific Sessions

Nice, France. 4-7 February 2015

\section{Background}

We previously reported that coronary distensibility can be measured non-invasively using 3T MRI and that distensibility is reduced in coronary artery disease (CAD) patients compared with healthy subjects. Because atherosclerotic vascular disease is an inflammatory process, we sought to test the hypothesis that coronary distensibility measured with MRI is associated with systemic inflammation, measured by serum high sensitivity $\mathrm{C}$ reactive protein, hsCRP, a marker of increased inflammation, and adiponectin, a fat hormone associated with decreased inflammation, in healthy subjects and in CAD patients.

\section{Methods}

25 subjects ( 8 healthy adults, age $=38.6 \pm 6.5$ years, mean \pm standard error) and 17 patients with catheterization-documented CAD (age=59.4 \pm 3.4 ) were studied using a commercial whole-body MR imaging system (Achieva 3.0T;Philips,Best,Netherlands). Spiral cine MRI was performed for area measurements of a proximal coronary artery. MRI parameters were:echo time $(\mathrm{TE})=1.5 \mathrm{~ms}$, radiofrequency $(\mathrm{RF})$ excitation angle $=20^{\circ}$; spectral spatial excitation, acq. window $=10 \mathrm{~ms}$, repetition time $(\mathrm{TR})=14 \mathrm{~ms}, 21$ spiral interleaves,spatial resolution(acquired/reconstructed $)=0.89 \times 0.89 \times 8.00 \mathrm{~mm}^{3} / 0.69 \times 0.69 \times 8.00 \mathrm{~mm}^{3}$. Blood pressure and heart rate were recorded. Images were analyzed for cross-sectional area in systole and diastole using semi-automated software (Cine vs3.15.17, General Electric), and distensibility $\left(\mathrm{mmHg}^{-1}\right)$ was determined as: [(systolic lumen area-diastolic lumen area)]/(pulse pressure multiplied by diastolic lumen area). Blood was obtained the

${ }^{1}$ Medicine, Johns Hopkins, Baltimore, MD, USA

Full list of author information is available at the end of the article same day as the MRI to quantify serum hsCRP and adiponectin (in a subset, $n=16$ ).

\section{Results}

Coronary distensibility was impaired in the CAD group, $\left(1.16 \pm 0.17 \mathrm{mmHg}^{-1}\right)$ as compared to that in the healthy subjects $\left(2.17 \pm 0.57 \mathrm{mmHg}^{-1} \mathrm{p}=0.05\right)$. Mean hsCRP was higher in the CAD group, $2.0 \pm 0.49 \mathrm{mg} / \mathrm{L}$, but did not differ significantly from that in the healthy group (1.47 $\pm 0.48 \mathrm{mg} / \mathrm{L}$ (range $0.4-5.5, \mathrm{p}=\mathrm{NS}$ ) and mean adiponectin levels also did not differ between the CAD $(8.1 \pm 1.71 \mu \mathrm{g} /$ $\mathrm{mL})$ and healthy $(11.2 \pm 1.52 \mu \mathrm{g} / \mathrm{mL}, \mathrm{p}=\mathrm{NS})$ groups. Although there was no relationship between hsCRP and coronary distensibility in healthy subjects $(R=0.36$, $\mathrm{p}=0.37$ ), there was a strong inverse relationship between CRP and distensibility in CAD patients $(R=-0.66$, $\mathrm{p}=0.003$, Figure $1 \mathrm{~A}$ ) and a positive relationship between adiponectin level and coronary distensibility in both the healthy and in the CAD subjects and the combined $\operatorname{group}(R=0.65, p=0.004$, Figure $1 B)$.

\section{Conclusions}

Coronary distensibility measured noninvasively by $3 \mathrm{~T}$ MRI is impaired in CAD patients compared to healthy controls and the degree of distensibility in CAD patients is inversely related to hSCRP level, a marker of inflammation. Adiponectin, a fat hormone known to suppress inflammation, is positively related to distensibility. These data suggest that systemic inflammation is closely related to coronary distensibility. Further studies are needed to determine whether suppressing inflammation improves coronary distensibility and other measures of vascular disease. 



Figure $1 \mathrm{~A}$ : Coronary artery distensibility $\left(\mathrm{mmHg}^{-1}\right)$ is inversely related to serum $\mathrm{hsCRP}$ (high sensitivity $\mathrm{C}$ reactive protein) level in patients with coronary artery disease ( $C A D, N=17)$. B: Adiponectiv (a fat hormone that suppresses inflammation) is positively related to coronary distensibility in $C A D$ patients and healthy adults combined $(\mathrm{N}=16)$.

\section{Funding}

NIH/NHLBI grants R01HL084186, AHA SDG 5200004, AHA 12PRE11510006.

\section{Authors' details}

'Medicine, Johns Hopkins, Baltimore, MD, USA. University of PIttsburgh,

Pittsburgh, PA, USA. ${ }^{3}$ German Heart Institute, Berlin, Germany.

Published: 3 February 2015

doi:10.1186/1532-429X-17-S1-P400

Cite this article as: Petrose et al.: Decreased coronary artery

distensibility measured using $3 \mathrm{~T} \mathrm{MRI}$ is related to systemic

inflammation in patients with coronary artery disease. Journal of

Cardiovascular Magnetic Resonance 2015 17(Suppl 1):P400.

Submit your next manuscript to BioMed Central and take full advantage of:

- Convenient online submission

- Thorough peer review

- No space constraints or color figure charges

- Immediate publication on acceptance

- Inclusion in PubMed, CAS, Scopus and Google Scholar

- Research which is freely available for redistribution

Submit your manuscript at www.biomedcentral.com/submit
C Biomed Central 